Research Article

\title{
Assessing the Impact of Climate and Change and Variability on Irish Potato (Solanum Tuberosum L.) Production from 1995 to 2015 in Tubah Sub Division, North West Region, Cameroon
}

\author{
Muh Blast Naintoh ${ }^{1}$, Mabel Nechia Wantim ${ }^{2}$ and Ayonghe Samuel Ndonwi ${ }^{3}$ \\ ${ }^{1}$ Department of Environmental Science; Faculty of Science; University of Buea, Cameroon \\ ${ }^{2}$ Department of Geography Faculty of Sciences Vrije Universiteit Brussel Pleinlaan 2, B-1050 Brussel \\ Belgium \\ ${ }^{3}$ UB Interdisciplinary Climate Change Laboratory, Faculty of Science, University of Buea, P .O Box 63, \\ Buea, Cameroon \\ Corresponding author: <samayonghe@yahoo.com>
}

\begin{abstract}
Climate change and variability are common phenomena that affect crop productivity globally but with significant differences between different regions of the world. Studies of the impacts of these phenomena on Irish potato -Solanum tuberosum L.-production within Tubah Sub-Division based on records of precipitation and temperatures from 1995 to 2015, indicated an increasing mean annual temperature rate of $0.09{ }^{\circ} \mathrm{C}$ per year and a slight increasing annual rainfall rate of $25.8 \mathrm{~mm}$ per year. Potato yields within the same period equally increased by $1.26 \mathrm{t} / \mathrm{ha}$ per year until 2012 when the yields started decreasing due to a correspondingly marked increase in both temperature and rainfall. The drop in potato yields has also been attributed to disease infestation such as potato blight and rot which are favoured by the increases in temperature and rainfall. Statistical correlation and regression analyses of these data revealed that the potato yields showed weak positive correlations with temperature $(\mathrm{R}=$ $0.02)$ and with rainfall $(\mathrm{R}=0.12)$. Results from questionnaire survey, focus group discussions and semistructured interviews indicated that the potato crop (63\%) of most farmers were negatively affected by climate change and variability through the increased sporadic rainfall which enhanced potato blight and rot. Some adaptation strategies to these climatic factors are already being practised by most farmers (81 $\%$ ) who are making use of a combination of fertilizers, pesticides, improved seeds and irrigation practices to remedy the situation although further approaches such as the use of resistant species are necessary towards improving on the dwindling potato yields.
\end{abstract}

Keywords: Climate, Change, Variability, Tubah Sub Division, Irish Potato, Adaptation Strategies, Cameroon.

Received: 11/04/2018

Accepted: 22/05/2018

DOI: https://dx.doi.org/10.4314/jcas.v14i2.2

(C) The Authors. This work is licensed under the Creative Commons Attribution 4.0 International Licence.

(C) The Authors. This work is licensed under the Creative Commons Attribution 4.0 International Licence. 


\section{RÉSUMÉ}

Le changement et la variabilité climatiques sont des phénomènes communs qui affectent la productivité des cultures à l'échelle mondiale, mais avec des différences significatives entre les différentes régions du monde. Les études des impacts de ces phénomènes sur la production de pommes de terre irlandaises Solanum tuberosum L.- dans l'arrondissement de Tubah sur la base des relevés des précipitations et des températures de 1995 à 2015, ont indiqué un taux de température annuel moyen croissant de 0,09 0C par an et un léger accroissement annuel des précipitations de $25,8 \mathrm{~mm}$ par an. Les rendements de pommes de terre au cours de la même période ont également augmenté de 1,26 t / ha par an jusqu'en 2012, lorsque les rendements ont commencé à diminuer en raison d'une augmentation correspondante marquée de la température et des précipitations à la fois. La diminution des rendements de pommes de terre a également été attribuée à l'infestation de maladies telles que la brûlure de la pomme de terre et la pourriture, qui sont favorisées par l'augmentation de la température et des précipitations. Les analyses de corrélation et de régression statistiques de ces données ont révélé que les rendements de la pomme de terre présentaient de faibles corrélations positives avec la température $(R=0,02)$ et avec les précipitations $(R=0,12)$. Les résultats de l'enquête par questionnaire, des groupes de discussion et des entrevues semi-structurées ont indiqué que la culture de la pomme de terre $(63 \%)$ de la plupart des agriculteurs a été affectée négativement par le changement et la variabilité climatiques à travers l'augmentation des précipitations sporadiques qui ont favorisé la brûlure et la pourriture de la pomme de terre. Certaines stratégies d'adaptation à ces facteurs climatiques sont déjà pratiquées par la plupart des agriculteurs (81\%) qui utilisent une combinaison d'engrais, de pesticides, de semences améliorées et de pratiques d'irrigation pour remédier à la situation, bien que d'autres approches telles que l'utilisation d'espèces résistantes soient nécessaires pour améliorer les rendements diminuants de pommes de terre.

Mots-clés : Climat, variabilité des changements, l'arrondissement de 'Tubah, rendements de la pomme de terre irlandaise, stratégies d'adaptation, Cameroun 


\section{INTRODUCTION}

Several pieces of evidence have shown that climate change is real and poses serious consequences on the suitability and productivity of current agriculture in specific agro-ecological zones of the world as well as on the incidence and severity of diseases affecting crops (IPCC, 2007). Recent warming of the climate system is suggested by the observations of increases in rising global average sea level, melting of snow and ice and global average air temperatures (IPCC, 2007). Global Climate Models project a rise in global temperature by $1.8^{\circ} \mathrm{C}$ to $4^{\circ} \mathrm{C}$ by the year 2100. According to NCAR (2016), climate change can affect food availability, access, utilization, and the stability of each of these over time. African countries are among the most vulnerable to climate change because their economies largely depend on climate-sensitive agricultural production systems (IPCC, 2007). Short term climatic variability has equally become more frequent and its impact on agriculture is felt across the continent.

In Cameroon, mean annual temperature has increased by 0.7 ÚC since 1960 at an average rate of 0.15 ÚC per decade and is projected to increase by 1.0 to 2.9 ÚC by the 2060 s and 1.5 to 4.7 ÚC by the 2090s while rainfall projections are less certain with anticipated change of between approximately $-7 \%$ and $+20 \%$ (Ayonghe, 2001; Meehl et al., 2007 \& IPCC, 2012). Agriculture remains the backbone of the economy of Cameroon and employs more than $70 \%$ of the population. However, it has been largely affected by oscillations in climatic elements; especially rainfall and temperature which have effects on both plantation and peasant agriculture (Molua \& Lambi, 2006). Solanum tuberosum L., commonly known as Irish potato, is the world's major noncereal food crop and the fourth largest crop after; maize, rice and wheat, with production reaching a record of 325 million tons in 2007 (FAOSTAT,
2008). It is also an important crop in Cameroon, ranking fifth in tons produced among the major staple crops cassava, plantain, cocoyam and maize) (Badu-Apraku et al., 2009).

Potato is grown in many different environments, but it is best adapted to temperate climates (Haverkort, 1990). At high temperatures usually above $17{ }^{\circ} \mathrm{C}$ (Stol et al., 1991), tuberization diminishes bringing about a decrease in potato yield (Reynolds \& Ewing, 1989). Borah \& Milthorpe (1962) and Bodlaender et al. (1964) discovered that potato plant needs a minimum temperature of $6{ }^{\circ} \mathrm{C}$ for seed tuber sprout development and emergence above the soil surface and a maximum of $18{ }^{\circ} \mathrm{C}$ for optimum stem elongation. High air and soil temperatures can also promote the build-up of soft rot bacteria, increase tuber infection and rotting of potatoes (Davidson, 1948). The crop grows best in cool but frost-free seasons and does not perform well in heat (Bodlaender, 1963 \& Hijmans, 2003).

The optimum precipitation for early potato ranges from $250 \mathrm{~mm}$ to $350 \mathrm{~mm}$ and any precipitation higher than this optimum leads to yield loss as it prolongs germination and sprouting and increases disease incidence (Rymuza et al., 2015). Monneveux et al. (2012) estimated the best precipitation requirement for potato to be between $500 \mathrm{~mm}$ to $700 \mathrm{~mm}$ for a 120 to 150 day growing season. Anochilli (1978) and N.P.C.K (2015), also reported that the optimum rainfall requirement of Irish potato ranges between $750 \mathrm{~mm}$ to $1250 \mathrm{~mm}$ per annum and $1200 \mathrm{~mm}-1800 \mathrm{~mm}$ respectively. There are many factors that affect potato yields such as; lack of water and nutrients in the soil, damage from pest and diseases and changes in weather variables (Ogola et al., 2011). Weather variables encompass; rainfall, temperature, wind, humidity and sunshine among others but the present study considered temperature and rainfall as the most critical elements affecting potato yields. 
Over 200,000 farmers grow potatoes in Cameroon, mostly smallholders. The Northwest and West regions are areas of greatest concentration, accounting for $80 \%$ of national production (Badu-Apraku et al., 2009). The study was limited to Tubah Sub Division which is an area with a high production of the crop (Fig. 1). Since potato is generally sensitive to environmental extremes, such as high temperature and limited soil moisture or low rain fall under a changing climate which cause yields to decrease, and since there is a constant increased demand for potato, these changing weather patterns are leaving food security at risk in the study area and Cameroon at large. However, there has been limited study on the state, severity and past trend of climate change and variability within this area from which adaptation strategies for growing this crop and ensuring future production can be conceived.

Thus, the present study is aimed at assessing the annual climatic trends (temperature and rainfall) and Irish potato production trends between 1995 and 2015. It also determines if there exist any statistical correlations between the trends of the climatic variables and potato yields and investigates how changes in temperature and rainfall have affected potato yields. Lastly, it verifies how potato farmers perceive the phenomenon of climate change and are adapting to changes in temperature and rainfall.

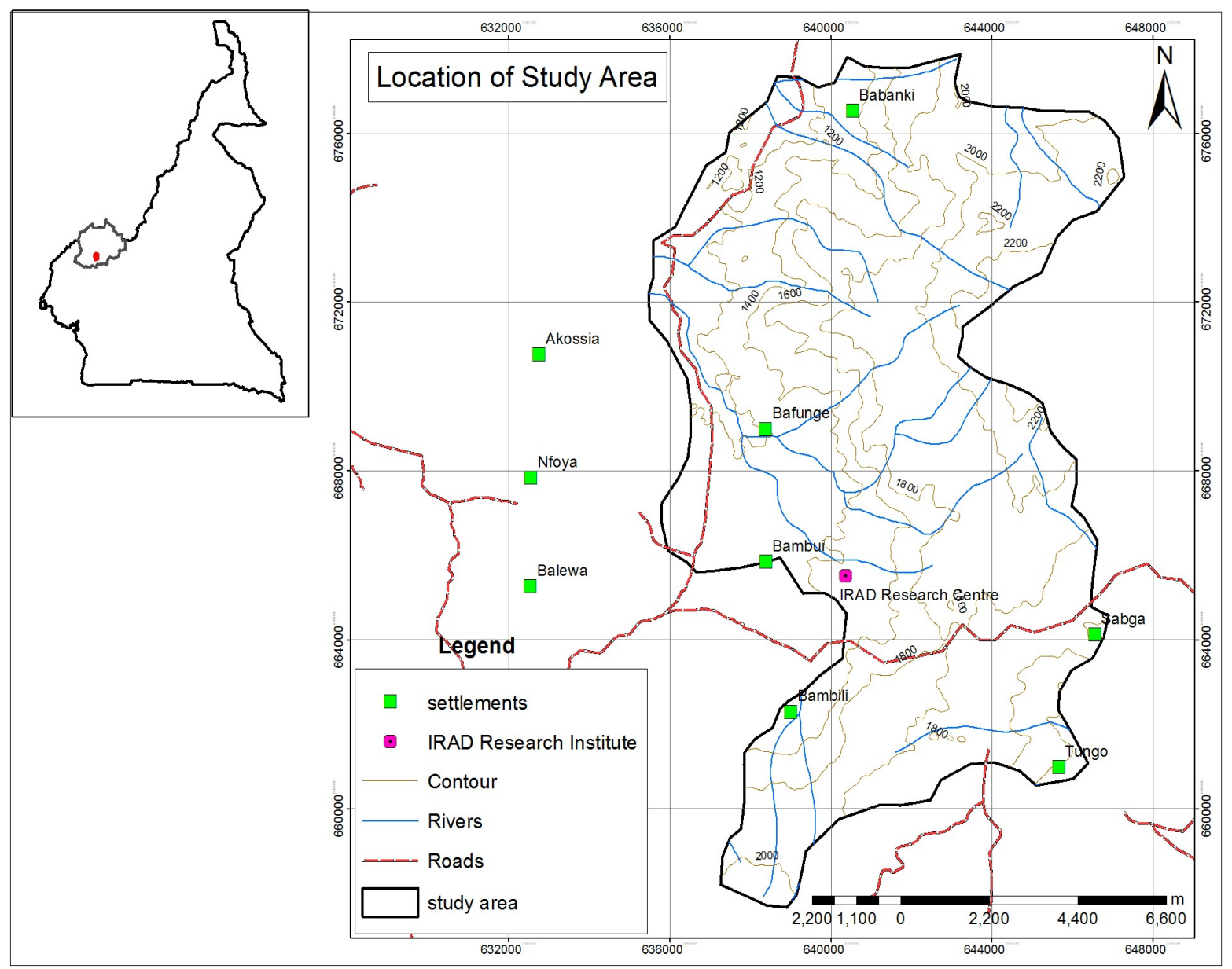

Figure 1: Location of Study Area (Adapted from Helvetas, 2001) 


\section{MATERIALS AND METHODS}

Climatic data (total annual rainfall and mean annual temperatures) from 1995 - 2015 were computed from data provided by the Meteorological Unit of the Ministry of Transport, Bamenda. Irish potato production data (in tons per hectare per year $(\mathrm{t} / \mathrm{ha} / \mathrm{yr}))$ for 21 years $(1995$ - 2015) in Tubah Sub Division were obtained at the Institute of Agronomic Research for Development (IRAD) in Bambui.

The method proposed by Ajadi et al. (2011), was used to process the agricultural production yield data and climate, whereby Excel 2010 was used to analyse variations in climatic trends and agricultural production trends with the correlation that exists between them within 1995 and 2015. The descriptive statistical techniques used in Excel 2010 to show the correlation that exists between climatic variables and potato yields were mean, standard deviation, correlation, and the regression inferential statistical technique. These analyses were presented in graphs and on tables.

A questionnaire design containing both structured and unstructured questions as used by Amon (2013) in his study of analysis of rainfall variability on Irish potato production in Ol-joroorok Division, Nyandarua country, Kenya, was self- administered to Irish potato farmers in order to find out their perception of the impact of climate change and variability on the potato crop and their adaptation strategies. A stratified purposive and random sampling technique as used by Regassa (2016) was adopted as a method of administering the questionnaires. The strata were the four fondoms of Tubah Sub Division namely: Kedjom Ketinguh, Kedjom Keku, Bambili and Bambui. For the purpose that Kedjom Ketinguh was the dominant producing area in terms of Irish potato, fifty (50) questionnaires were administered to farmers randomly while thirty (30) were administered to each of the remaining three strata, given that they produce Irish potato in small quantities making a total of 140 questionnaires. The questionnaires were analysed using Excel 2010 whereby, results were presented on pie charts, bar charts, columns and tables.

Focused Group Discussions (FGDs) were also held with some of the Irish potato farmers group within the sub division to get information on the impact of climate change and variability on potato and how they are adapting to the changes in temperature and rainfall. A checklist was used to obtain information during the FGDs. The following potato farming groups were used: Akungni Farming Group and Ntamengon Integrated Association Farming Group in Bambui, Kwecham Nimui Social Group in Bambili, as well as the Struggling Men Famers Group and Abohfen Promised Land Farmers Group in Kedjom Ketinguh.

Ground control points were collected from Irish potato farms in the four fondoms within the sub division with the use of a Garmin GPS to produce a locational map of some Irish potato farms. The ArcGIS 9.2 software was used to produce the location map of Irish potato farms within the four fondoms (figure 2).

\section{RESULTS}

Trend analyses of mean annual temperature and total annual rainfall between 1995 and 2015, are presented in figures $3 \mathrm{a}$ and $3 \mathrm{~b}$ respectively. Mean annual temperature showed an increasing warming trend of about $0.09{ }^{\circ} \mathrm{C}$ per year (figure 3a) while total annual rainfall showed an increasing trend of about $25.80 \mathrm{~mm}$ per year (figure $3 \mathrm{~b}$ ). The potato yields by contrast showed an increasing trend from 1995 until 2012 when it started dropping with time (figure 4). 


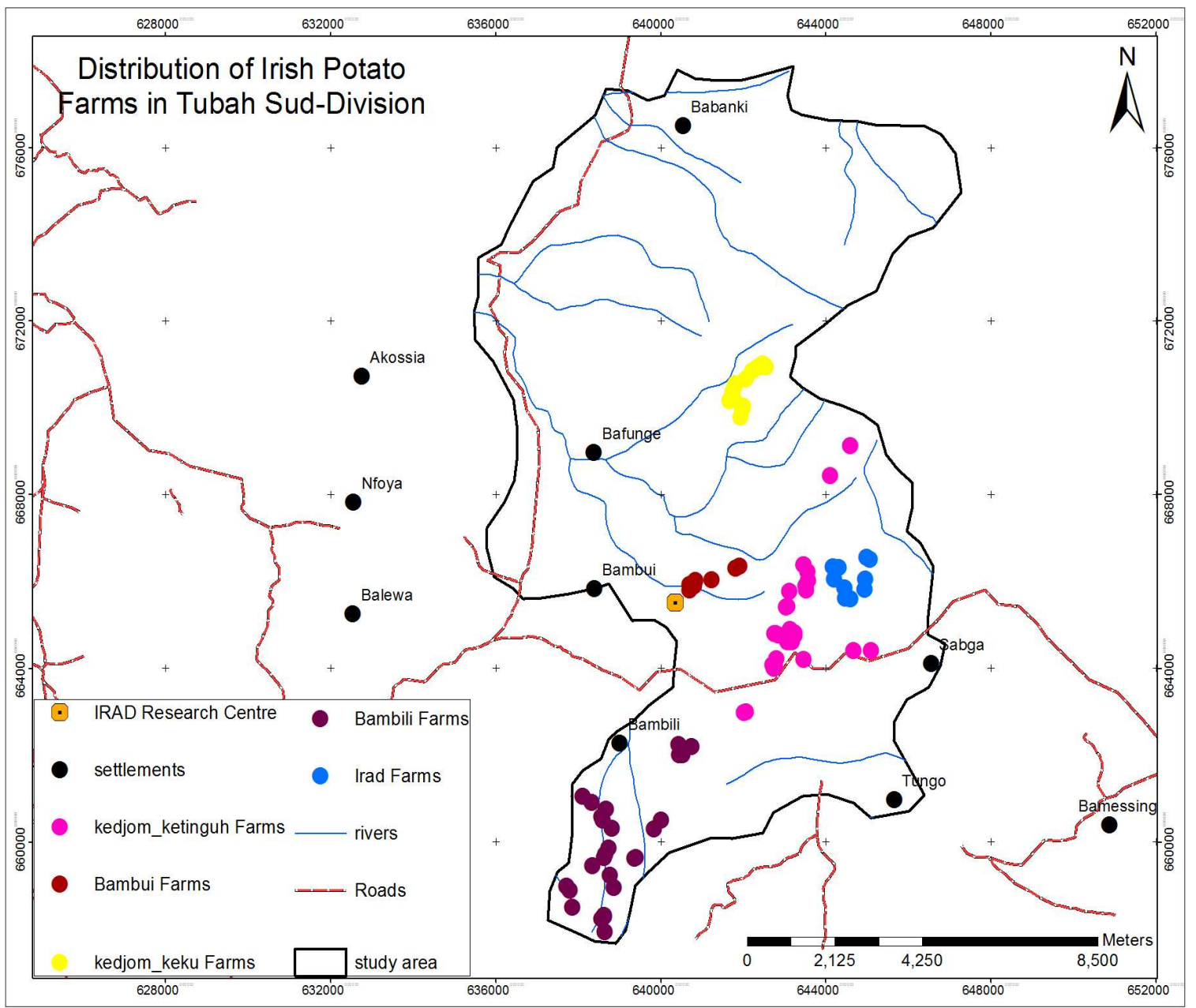

Figure 2: Distribution of Irish Potato Farms within Tubah Sub Division

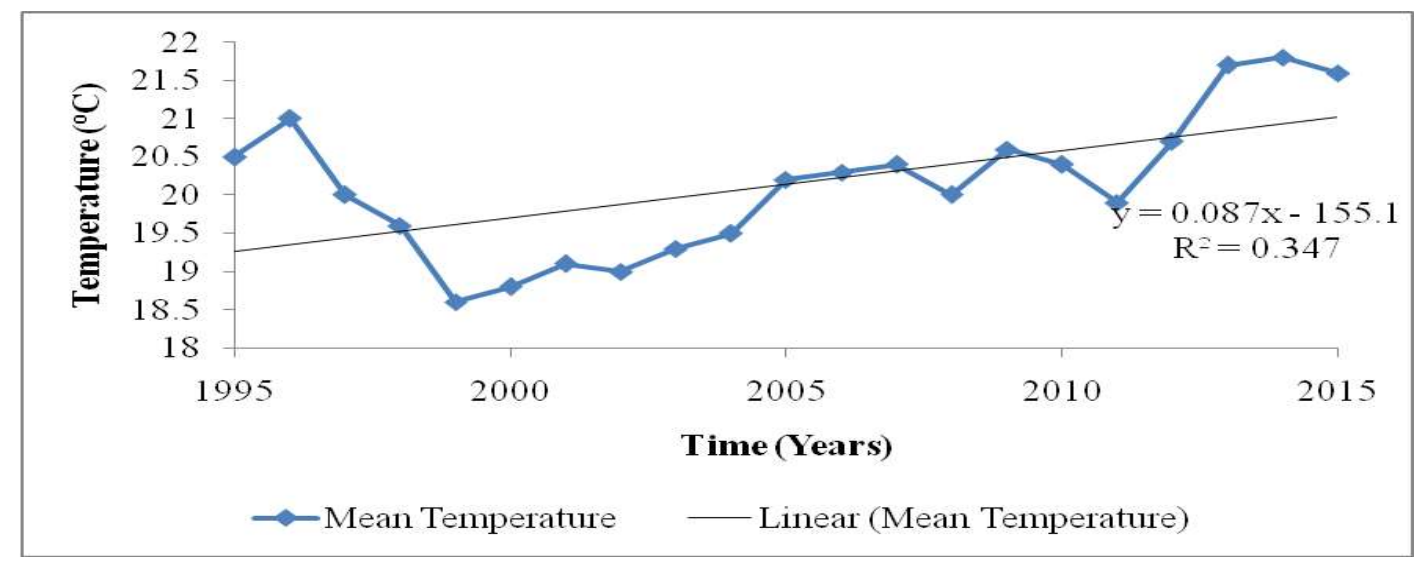

Figure 3a: Mean Annual Temperature Trend in Tubah Sub Division (1995 - 2015) 


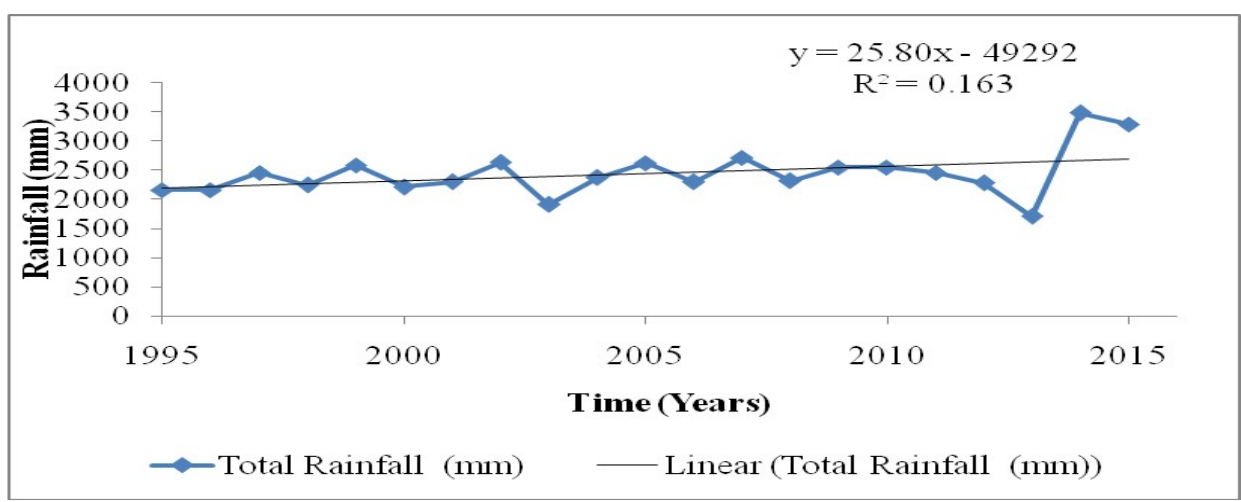

Figure 3b: Total Annual Rainfall Trend in Tubah Sub Division (1995 - 2015)

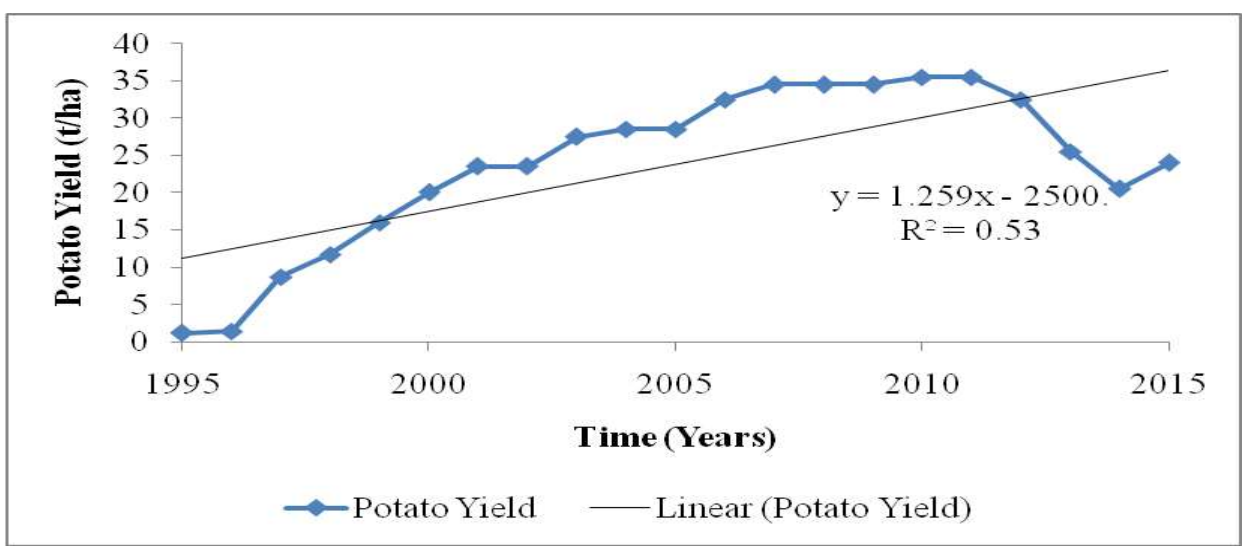

Figure 4: Annual Trend of Irish Potato Yield in Tubah Sub Division (1995 - 2015)

\section{Relationship between temperature and potato yields}

Correlation and regression analyses of the climatic parameters and Irish potato yields from 1995 to 2015 are presented (Figures 5 and 6 and Table 1). Potato yields were increasing with increasing temperature (Figure 5).

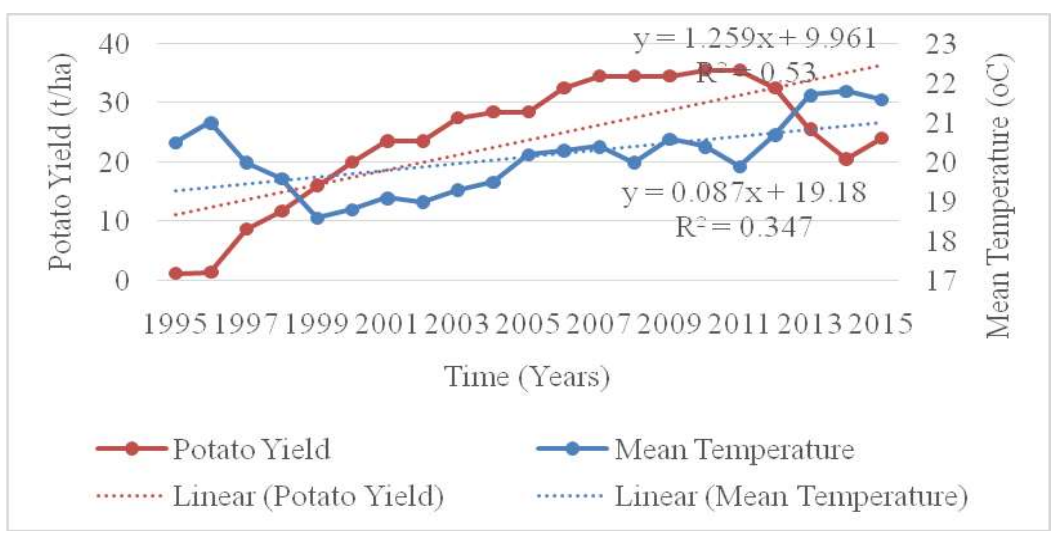

Figure 5: Correlation and Regression Analyses of Mean Annual Temperature and Potato Yield Trends in Tubah Sub Division (1995 - 2015) 


\section{Relationship between rainfall and potato yields}

In Tubah Sub division, potato yields increased with a slight increasing rainfall trend (Figure 6). From the regression analyses (Table 1$)$, rainfall and yields had a weak positive correlation $(\mathrm{R}=0.12)$. The relation was not significant at $95 \%$ Confidence Interval $(\mathrm{PV}=0.61)$ and rainfall explained only $1.42 \%$ $\left(\mathrm{R}^{2}=0.014201\right)$ of the variation in yields.

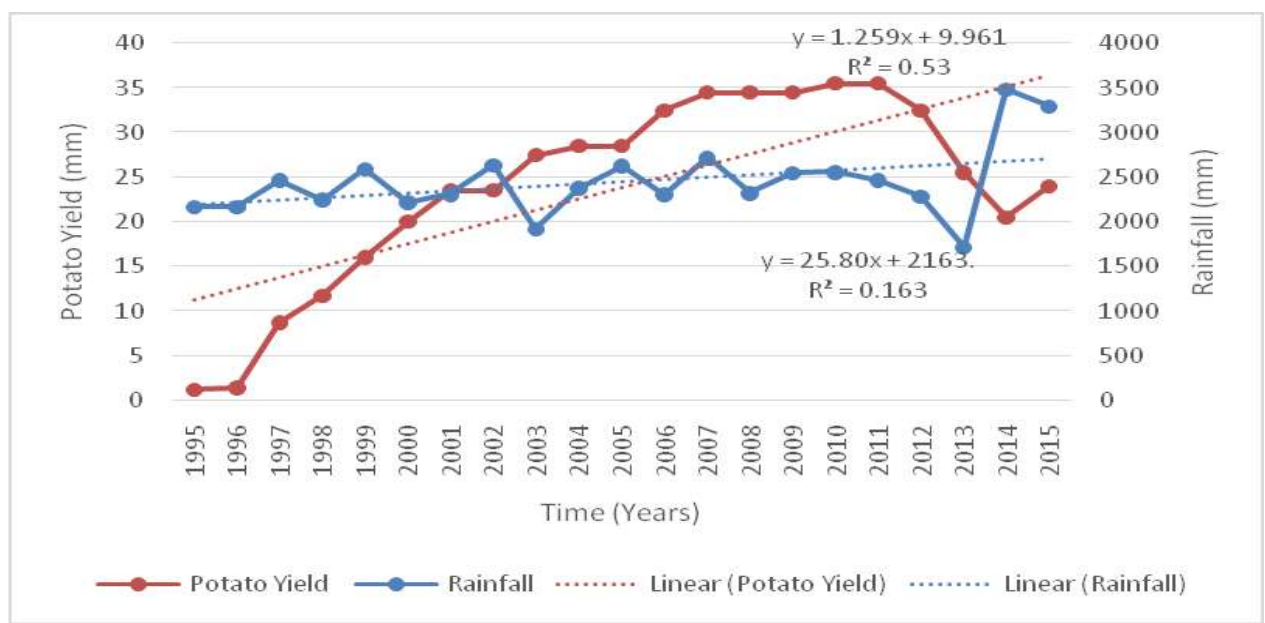

Figure 6: Correlation and Regression Analyses of Total Annual Rainfall and Potato Yield Trends in Tubah Sub Division (1995 - 2015)

Table 1: Regression Summary Output for Rainfall and Potato Yields in Tubah Sub Division (1995 - 2015)

\begin{tabular}{lc}
\hline \multicolumn{2}{l}{ Regression Statistics } \\
\hline Multiple R & 0.119167 \\
R Square & 0.014201 \\
Adjusted $\quad \mathrm{R}$ & \\
Square & -0.03768 \\
Standard & \\
Error & 10.93044 \\
Observations & 21 \\
\hline
\end{tabular}

\begin{tabular}{llllll} 
ANOVA & \multicolumn{5}{l}{} \\
\hline & $d f$ & $S S$ & $M S$ & $F$ & Significance F \\
\hline Regression & 1 & 32.7003 & 32.7003 & 0.273701 & 0.606908 \\
Residual & 19 & 2270.018 & 119.4746 & & \\
Total & 20 & 2302.718 & & & \\
\hline
\end{tabular}

\begin{tabular}{|c|c|c|c|c|c|c|c|c|}
\hline & Coefficients & $\begin{array}{l}\text { Standard } \\
\text { Error }\end{array}$ & $t$ Stat & P-value & Lower $95 \%$ & Upper $95 \%$ & $\begin{array}{l}\text { Lower } \\
95.0 \%\end{array}$ & $\begin{array}{l}\text { Upper } \\
95.0 \%\end{array}$ \\
\hline Intercept & 15.89978 & 15.30604 & 1.038791 & 0.311942 & -16.1361 & 47.93569 & -16.1361 & 47.93569 \\
\hline Rainfall & 0.003232 & 0.006178 & 0.523164 & 0.606908 & -0.0097 & 0.016164 & -0.0097 & 0.016164 \\
\hline
\end{tabular}

\section{Farmers' awareness of climate change and} its impacts

From the pie chart (Figure 7a), most (95\%) of respondents were aware of the impacts of climate change (changing rainfall and temperature patterns between 1995 and 2015) with the majority ( $53 \%)$ indicating that climate change was affecting Irish potato yields in the study area (Figure $7 b$ ). 


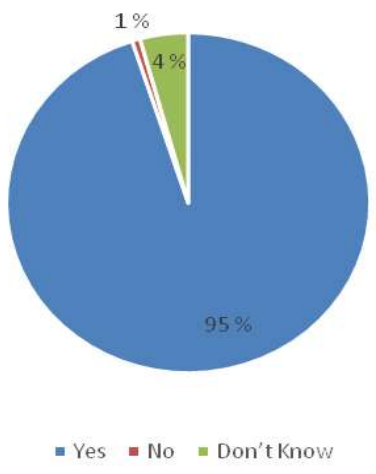

Figure 7a: Farmers Awareness of climate change and its impacts

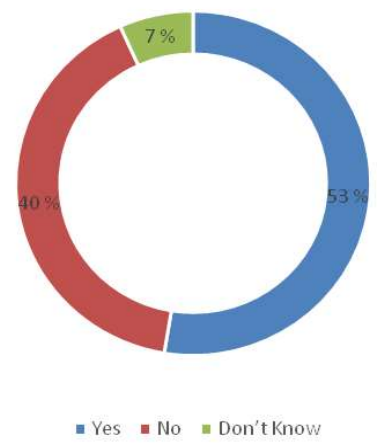

Figure 7: Farmers awareness and perspective on a. climate change in Tubah Sub Division and b. the consequences of climate change (Temperature and Rainfall) on Potato Yields in Tubah Sub Division
Based on Figure 8, $43 \%$ of farmers attested to the fact that increased rain affected potato yields, followed by $36 \%$ who said both increased rain and increased temperature affected potato yields.

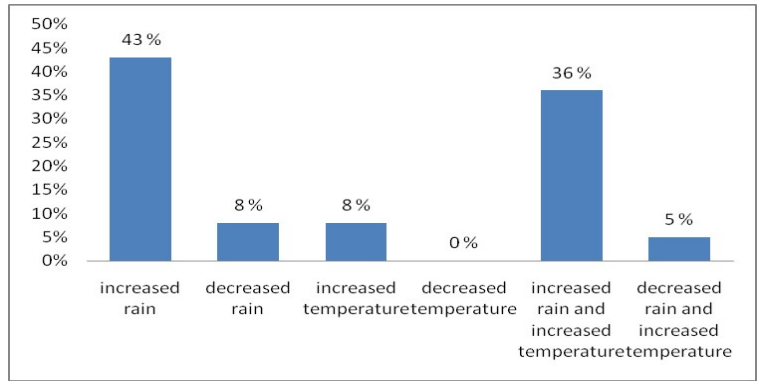

Figure 8: Aspect of Climate Change Affecting Potato Yields in Tubah Sub Division (1995 - 2015)

The majority of farmers (63\%), confirmed that potato blight and potato rot affected potato yields in Tubah Sub Division (Kedjom Ketinguh, Kedjom Keku, Bambili and Bambui) (Table 2 and figure $9 \mathrm{a}$ and $\mathrm{b})$.

Table 2: Impact of Climate Change on Irish Potato Yields in Tubah (1995 - 2015)

\begin{tabular}{|c|c|c|c|c|c|c|}
\hline Impact & $\begin{array}{l}\text { Kedjom } \\
\text { Ketinguh }\end{array}$ & $\begin{array}{l}\text { Kedjom } \\
\text { Keku }\end{array}$ & Bambili & Bambui & Total & $\begin{array}{l}\text { Percen } \\
(\%)\end{array}$ \\
\hline $\mathrm{A}=$ potato blight and potato rot & 8 & 12 & 10 & 14 & 44 & 63 \\
\hline $\begin{array}{l}\mathrm{B}=\text { delay in potato flowering and } \\
\text { tuberization }\end{array}$ & 0 & 3 & 1 & 0 & 4 & 6 \\
\hline$C=$ shortage of water for crops & 1 & 3 & 0 & 0 & 4 & 6 \\
\hline $\begin{array}{l}\mathrm{D}=\text { Potato blight and rot, delay in } \\
\text { flowering and tuberization }\end{array}$ & 3 & 3 & 1 & 6 & 13 & 18 \\
\hline $\begin{array}{l}\mathrm{E}=\text { shortage of water and delay } \\
\text { in flowering and tuberization }\end{array}$ & 1 & 0 & 0 & 1 & 2 & 3 \\
\hline $\begin{array}{l}\mathrm{F}=\text { Potato blight and rot, delay in } \\
\text { flowering and tuberization, } \\
\text { shortage of water for crops, }\end{array}$ & 2 & 0 & 0 & 1 & 3 & 4 \\
\hline Total & 15 & 21 & 12 & 22 & 70 & 100 \\
\hline
\end{tabular}



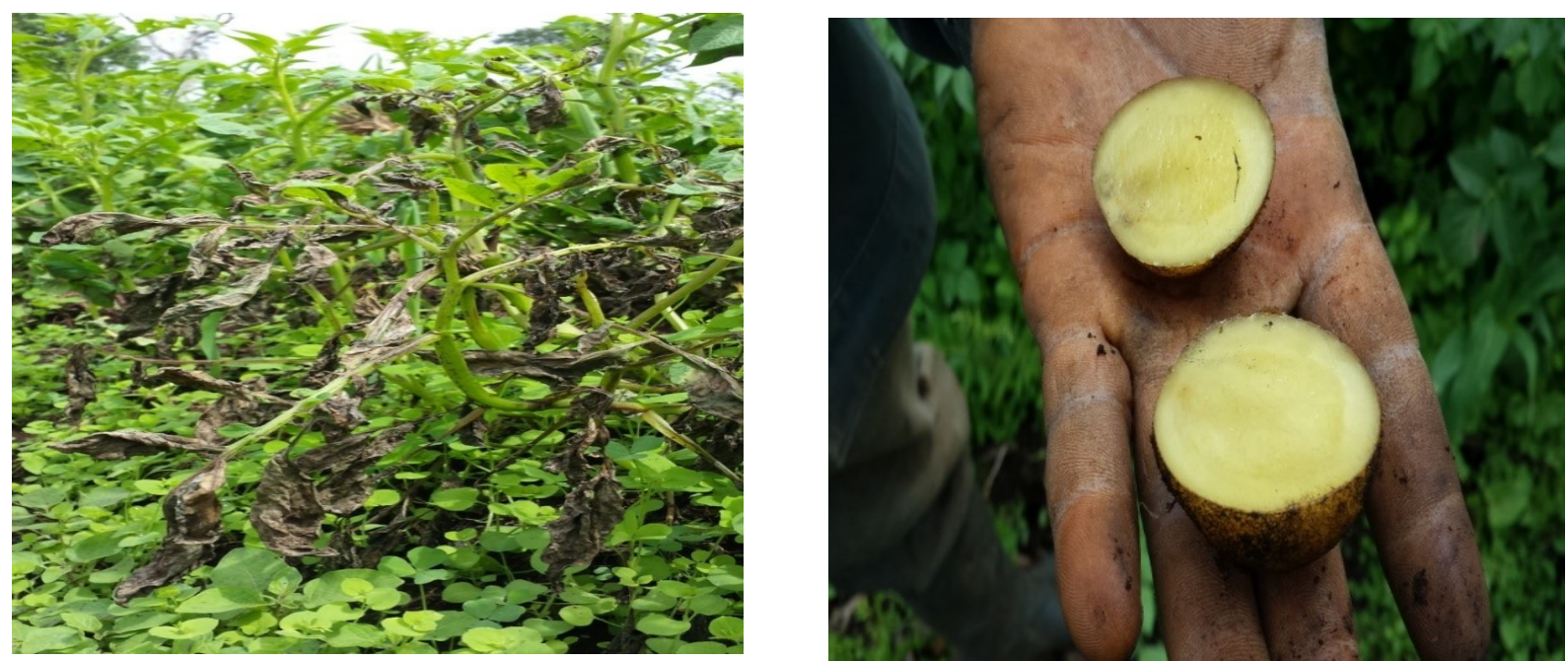

Figure 9: Photographs showing (a): a potato plant affected by blight which appears as dark leaves on the plant and (b): potato rot on the hand.

The majority (81\%) of farmers (Figure 10) were using climate change adaptation strategies for potato production and $32 \%$ of them used improved seeds, irrigation, fertilizer and pesticide as measures to adapt to climate change (Table 3 ).

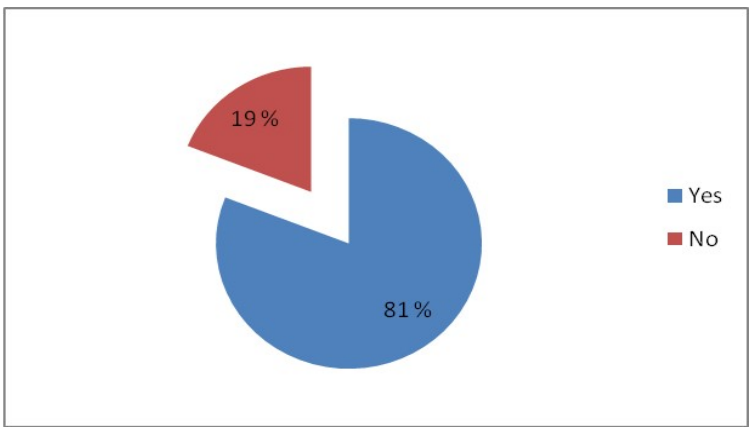

Figure 10: Number of Farmers Using Climate Change Adaptation Measures for Potato Production in Tubah Sub Division (1995-2015).

Table 3: Farmers Adaptive Measures to Temperature and Rainfall Changes in Tubah Sub Division

\begin{tabular}{lllllll}
\hline Adaptation Measures & $\begin{array}{l}\text { Kedjom } \\
\text { Ketinguh }\end{array}$ & $\begin{array}{l}\text { Kedjom } \\
\text { Keku }\end{array}$ & Bambili & Bambui & Total & $\begin{array}{l}\text { Percentage } \\
\mathbf{( \% )}\end{array}$ \\
\hline A= improved seeds & 1 & 0 & 0 & 0 & 1 & 1 \\
B= irrigation & 1 & 0 & 0 & 3 & 4 & 7 \\
C= pesticide & 2 & 7 & 2 & 0 & 11 & 19 \\
D= fertilizer & 2 & 0 & 0 & 0 & 2 & 4 \\
E= improved seeds, & 2 & 0 & 5 & 6 & 13 & 23 \\
pesticide and fertilizer & & & & & & \\
F= improved seeds and & 0 & 0 & 0 & 8 & 8 & 14 \\
fertilizer & & & & & & \\
G= improved seeds, & 6 & 3 & 6 & 3 & 18 & 32 \\
irrigation, pesticide and & & & & & & \\
fertilizer & & & & & & \\
\hline Total & $\mathbf{1 4}$ & $\mathbf{1 0}$ & $\mathbf{1 3}$ & $\mathbf{2 0}$ & $\mathbf{5 7}$ & $\mathbf{1 0 0}$ \\
\hline
\end{tabular}




\section{DISCUSSION}

Temperature and rainfall trends in Tubah Sub Division had increased between 1995 and 2015 in conformity with the statement of the IPCC (2007) that, recent warming of the climate system is obvious as it is now evident from observations of increases in global average air temperatures, melting of snow and ice, and rising global average sea level, and that, global surface temperature has increased by $0.74{ }^{\circ} \mathrm{C}$ during the hundred years ending in 2005. The warming trend of about $0.09{ }^{\circ} \mathrm{C}$ per year in the study area from 1995 to 2015 is an indication that the area will be hard hit by global warming in the nearest future. The slight increasing rainfall trend is in line with the findings of Hulme et al. (2001) that, West Africa has experienced an increase in rainfall during the past 10 years when contrasted from the extended droughts years from the 1960s to the 1990s during which annual average rainfall decreased by as much as $30 \%$.

The correlation analysis of potato yield and temperature showed that there was no significant relationship between the two variables as PV was 0.94 at $95 \%$ confidence interval and potato yields had a very weak positive relationship with temperature $(\mathrm{R}=0.02)$. Temperature had very little effect $(0.03 \%)$ on potato yields between 1995 and 2015. This is contrary to what Ambrose (2013) discovered in his findings that, temperature has a significant positive correlation with Irish potato yields in Nigeria.

Even though, there has been an increasing trend between the two variables, a decrease in temperature as experienced in 1996 from $21.0{ }^{\circ} \mathrm{C}$ to $19.9{ }^{\circ} \mathrm{C}$ in 2011 led to a continuous increase in potato yields from $1.4 \mathrm{t} / \mathrm{h}$ a to $35.5 \mathrm{t} / \mathrm{ha}$. The rise in temperature as observed between 2012 and $2014\left(20.7{ }^{\circ} \mathrm{C}-21.8^{\circ} \mathrm{C}\right)$ led to a rapid decrease in potato yields from $32.5 \mathrm{t} / \mathrm{ha}$ to $20.5 \mathrm{t} / \mathrm{ha}$. This means that potato yields tend to decrease only when temperatures are $20.7{ }^{\circ} \mathrm{C}$ and above, which confirms what Rymuza et al. (2015) observed that potato productivity is greatly reduced at temperatures higher than the optimum of $20{ }^{\circ} \mathrm{C}$ as, the rates of photosynthesis and respiration are affected with the former being reduced and the latter increased. Levy \& Veilleux (2007) and Monneveux et al. (2012) also observed that increases in either day or night temperature above optimal levels $\left(18{ }^{\circ} \mathrm{C}-20^{\circ} \mathrm{C}\right)$ reduce tuber yields. The correlation analyses of rainfall and potato yields showed a continuous increasing trend in yields from 1995 to 2011 (1.2 t/ha to 35.5 t/ha) with a slight increase in rainfall from $2166.4 \mathrm{~mm}$ to $2463.7 \mathrm{~mm}$. But 2014 experienced a rapid decline in yields $(20.5 \mathrm{t} / \mathrm{ha})$ as a result of an increase in rainfall to $3482 \mathrm{~mm}$. This means that, only rainfall extremes of $3000 \mathrm{~mm}$ and above negatively affect yields in Tubah. This is contrary to what NPCK (2015) reported in Kenya that, the optimum rainfall requirement of Irish potato ranges between $1200 \mathrm{~mm}$ and $1800 \mathrm{~mm}$. Results showed that rainfall contributed only $1.42 \%$ of the variation in potato yields in Tubah, meaning that factors other than rainfall like; temperature, relative humidity, pest and diseases, relief and soil temperature explain the remaining $98.58 \%$ of variation in yields.

An assessment of climate change awareness by the farmers showed that $95 \%$ were already aware of this phenomenon and its impacts prior to this study. This is in line with what Falaki et al. (2013) observed in his findings that the majority of the farmers in North Central Nigeria were already aware of climate change and its effects. Fifty three percent $(53 \%)$ of those who were aware said climate change was affecting potato yields in the study area, which confirms IPCC (2007) findings that, the impacts of climate change such as; rising global average temperature and changes in precipitation are undeniably clear with impacts already affecting ecosystems, biodiversity and human systems throughout the world.' 
Forty-three $(43 \%)$ percent of the farmers who said climate change was affecting potato yields emphasized that, increased rainfall was the main cause while $36 \%$ were of the opinion that potato yields are highly affected by increased rain followed by increased temperature. This is in line with what IPCC (2007) stated that, increasing temperature and precipitation may be the reason that potato crops in many regions which previously had no presence of late blight disease have become affected in recent years.

Sixty-three $(63 \%)$ percent of the farmers stated that potato blight and rot were caused by increases in both rainfall and temperature which is in line with the findings of Olanya et al. (2006) that, late blight was regarded by farmers in Nyandarua as the most common disease in potato resulting from high rainfall. High air and soil temperatures can also promote the build-up of soft rot bacteria, increase tuber infection and rotting of potatoes (Davidson, 1948).

With regards to adaptation measures, $81 \%$ of the farmers were already aware of the impacts of climate change. This confirms what IPCC (2007) said, that adaptation to climate change as far as agriculture is concerned is already taking place as farming communities have a long record of coping and adapting to the impacts of weather and climate on potato. Thirty one percent were already using a combination of improved seeds, fertilizer, pesticide and irrigation as strategies to limit the impact of changes on potato yields. Some of these strategies confirm what Moldovan et al. (2011) recommended that, improved potato seeds can be used as a measure to adapt to climate change and increase potato yields. Fry and Shtienberg (1990) also stated that protectant pesticides should be frequently applied to destroy blight in potato plant.

\section{CONCLUSION}

The continuous increase in temperature $\left(0.09{ }^{\circ} \mathrm{C}\right.$ per year) and rainfall (25.80 mm per year) between 1995 and 2015 has led to slight increases in yields (1.26 t/ha/yr), though with accompanying increases in disease infestations, with greatest decline in yields $(-20.5 \mathrm{t} / \mathrm{ha})$ recorded in 2014 . Irish potato yields correlation with climatic elements equally had different relationships. Yields have been increasing with temperature, even though the relation was a very weak positive one $(\mathrm{R}=0.02)$ while in terms of rainfall, potato yields at $\mathrm{R}=0.12$. Yields increased with increasing rainfall but started decreasing only when rainfall was at extremes $\left(3000 \mathrm{~mm}^{+}\right)$. Furthermore, temperatures of $20.7{ }^{\circ} \mathrm{C}^{+}$decreased yields from 2012 to 2014 (32.5 t/ ha to 20.5 t/ha). These changes were associated with disease infestations of the crop in the form of potato blight and rot arising from both increases in rainfall and temperatures. Most farmers were already using improved seeds that are disease resistant together with pesticides and fertilizers against these effects. However, potato crops could not sustain the climatic extremes that occurred between 2012 and 2014 whereby temperatures increased from 19.9 ${ }^{0} \mathrm{C}$ to $21.8{ }^{\circ} \mathrm{C}$ with an accompanying significant increase in rainfall from $2282.4 \mathrm{~mm}$ to $3482 \mathrm{~mm}$. Even though rainfall and temperature affected potato yields in the study area, the climatic variables did not correlate significantly with Irish potato production. This means that temperature and rainfall may not be the most critical climatic variables affecting potato yields and that other climatic variables such as evaporation, relative humidity, sunshine hours, soil temperature, as well as climate variability which affects the onset dates of rains, dry spell or drought, are equally important parameters to be considered in such studies.

Other parameters that may affect the potato yields may include poor farm management practices such as failure in allowing the land to fallow, the poor timing of planting the potato with respect 
to the start of the rainy season, and/or the impacts of insufficient rainfall at the early stages of growth. The remedial strategies will include ensuring that the land is fallowed every other year and the provision of irrigation facilities whenever the rainfall is insufficient. The cultivation of other Irish potato varieties that have been recommended for Sub Saharan Africa in the International Potato Centre's (CIP) list, especially species that are more heat tolerant and late blight resistant to current climatic conditions are highly recommended for this area.

\section{ACKNOWLEDGEMENTS}

Partial funding towards the realisation of this study was provided by the USAID/OFDA grant through the UBuea Consortium of the Periperi U project. Field assistance from the Management Unit of Tubah Sub Delegation of Agriculture (and the President at Mezam/Momo Potato Producer Cooperative (Mr Markeh Francis) especially during the questionnaire management is highly appreciated. IRAD Bambui, under the consultancy of Dr Njualem Dominic, is equally appreciated for providing the data on potato yields. The Meteorological Unit under the Ministry of Transport, Bamenda provided the climatic data and their support is highly acknowledged.

\section{REFERENCES}

Ajadi B.S., Adeniyi A. \& Afolabi M.T. (2011): Impact of Climate on Urban Agriculture: Case Study of Ilorin City, Nigeria. Global Journal of Human Social Science Volume 11 Issue 1, Type: Double Blind Peer Reviewed International Research Journal Publisher: Global Journals Inc. (USA).

Ambrose A Zemba, Solomon Z. Wuyep, Abel A. Adebayo, and Clement J. Jahknwa (2013). Growth and Yield Response of Irish Potato (Solanum
Tuberosum) to Climate in Jos-South, Plateau State, Nigeria. Global Journal of Human-Social Science Research, [S.1.], july 2013. ISSN 2249-460X.

Amon M.K. (2013): Analysis of Rainfall Variability on Irish Potato Production in OlJoro-Orok Division, Nyandarua County, Kenya.

Anochilli B. C. (1978): Food Crop for Tropical Agriculture, Macmillan Press Limited, 16-18.

Ayonghe S.N. (2001): A quantitative evaluation of global warming and precipitation

in Cameroon from 1930 to 1995 and projections to 2060: Readings in Geography. Lambi C (Ed.) $142-155$

Badu-Apraku B, Fakorede M A B, Lum A F, Akinwale R. 2009. Improvement of yield and other traits of extra-early maize under stress and nonstress environments. Agron. J. 101: 381-389 Crossref. 5.

Bodlaender K.B.A. (1963): Influence of Temperature, Radiation and Photoperiod on Development and Yield. Ingrowth of the Potato,ed.J.D. Ivins and F.L. Milthorpe, 199210. London: Butterworths.

Bodlaender K.B.A., Lugt C. \& Marinus J. (1964): The Induction of Second- Growth in Potato Tubers. European Potato Journal7: 57-71.

Borah M.N. \& Milthorpe F.L. (1962): Growth of the Potato as Influenced by Temperature. Indian J Plant Physiol 5:53-72.

Davidson R.S. (1948): Factors Affecting the Development of Bacterial Soft Rot of Potato Tuber Initials. Phytopathology 38:673-687.

Falaki A. A., Akangbe J. A and. Ayinde O. E (2013). Analysis of Climate Change 
and Rural Farmers' Perception in North Central Nigeria.

A.A. Falaki1, J. A. Akangbe1 and O. E. Ayinde2*. 1Department of Agricultural Extension and Rural Development,. University of Ilorin, Ilorin, Nigeria. (C) Kamla-Raj 2013 J Hum Ecol, 43(2): 133-140 (2013).

FAOSTAT (2010): http://faostat.fao.org.

FAOSTAT (2008): Climate Change Adaption and Mitigation in the Food and Agricultural Sector. Technical Background Document from the Expert Consultation held on 5-7 of March $2008 \mathrm{ftp}: / /$ ftp.fao.org/docrep/fao/meeting/013/ ai782e.pdf.

Fry W.E. \& Shtienberg D. (1990): Integration of Host Resistance and Fungicide to Manage Potato Diseases. Canadian Journal of Plant Pathology 12:111-16.

Haverkort A.J. (1990): Ecology of Potato Cropping Systems in Relation to Latitude and Altitude. AgrSyst 32:251 272.

Helvetas Cameroon (2001): Tubah Council Monographic Study.

Hijmans R.J. (2003): The effect of Climate Change on Global Potato P r o d u c t i o n . American Journal of Potato Research, 80: 271-280.

Hulme M., Doherty R., Ngara T., New M. \& Lister D. (2001): African Climate Change: 19002100. Clim Res. http://dx.doi.org//10.3354/ cr017145.

IPCC (2001): Climate Change Impacts, Adaptation and Vulnerability. Contribution of Working Group II to the Third Assessment Report of the Intergovernmental Panel on Climate Change. Cambridge University Press, Cambridge. IPCC (Fourth Assessment Report of the Intergovernmental panel on Climate Change), (2007): The Impacts, Adaption and Vulnerability (WG III). Cambridge University press, United Kingdom and New York, NY,USA.

IPCC (2012): Managing the Risks of Extreme Events and Disasters to Advance Climate Change Adaptation. Special Report of the Intergovernmental Panel on Climate Change. Cambridge University Press, Cambridge.

Levy D.\& Veilleux R. (2007): Adaptation of Potato to High Temperatures and Salinity-A Review. American Journal of Potato Research 84 (6): 487-506.

McCarthy J., Canziani O., Leary N., Dokken D. \& White K. (2001): Climatem Change 2001: Impacts, Adaptation, and Vulnerability. New York, Cambridge University Press.

Meehl N., McSweeney C. \& Lizcano G. (2007): Tyndall Centre for Climate Change Research. (http://country-profiles.geog.ox.ac.uk).

Moldovan C., Morar G., Vatca S. \& Todoran F. (2011): "Research Concerning t h e Influence of Photoperiod upon Stolonization and Tuberization." Bulletin UASVM Agriculture, 68(1)/2011: 224-230.

Molua E. \& Lambi C. (2006): The Economic Impact of Climate Change on Agriculture in Cameroon. CEEPA Discussion Paper No. 17 Special Series on Climate Change and Agriculture in Africa ISBN 1-920160-01- 9 http:/ Lwww.ceepa.co.za/docs/CDPNo17.

Monneveux P., Quiroz R., Posadas A. \& Kleinwechter U. (2012): Facing Climate Change 
Effects on Potato Cultivation: An Integrative Approach.

NCAR (2016). Climate Change and Global Food Security Report for the U.S. National Climate Assessment. Report

NPCK 2015. Harnessing Kenya;s great potato production potential. Hortfresh Journal

May-June 2015 hortfreshjournal.com/old/articles/ npck\%20potato.pdf National Potato Council of Kenya

Ogola O., Milton, W., Ayieko, A., Orawa, O., Kimani, W. (2011): Analysis offertilizer use in potato production in Nakuru district, Kenya. Africa journal of Agriculture vol.6 (16):3672-3677.

Olanya O., Lunjaho C., Nderitu S., Kabura J., ElBedewy R. \& Waling A. (2006): Yield Performance and Release of Four Late Blight Tolerant Potato Varieties in Kenya. Journal on. Agro S: 57-61.

Potato Association of America (P.A.A) (2010): Second Revision of American Potato Journal Supplement Volume 57 and USDA Handbook 267. Regassa A. E. (2016): Income Determinants of Irish Potato (Solanum tuberosum L.) Growers: The Case of West Arsi Zone of Oromia Regional State, Ethopia. Net J Agric Sci, 4(1): 1-8.

Reynolds M. P.\& Ewing E. E. (1989): Effects of High air and Soil Temperature Stress on Growth and Tuberization in Solanum tuberosum.

Annals of Botany, 64, 241-247.

Rymuza K., Radzka E. \& Lenartowicz T. (2015): The Effect of Weather Conditions on Early Potato Yields in East-Central Poland.

Communications in Biometry and Crop Science10, 6572.
Stol W., Koning G.H., Haverkort A.J., Kooman P.L., van Keulen H.\&Penning F.W. (1991): Agroecological Characterization for Potato Production. A Simulation Study at the Request of the International Potato Center (CIP), Lima, Peru.CABO-DLO, Report 155. 